\title{
Purification and Characterization of Thermostable Purine Nucleoside Phosphorylase of Bacillus stearothermophilus JTS 859
}

\author{
Nobuaki Hori, Mutsumi Watanabe, Yoshinari YAMAZAKI \\ and Yoichi MIKAMJ \\ Tobacco Science Research Laboratory, Japan Tobacco Inc., \\ 6-2 Umegaoka, Midori-ku, Yokohama 227, Japan
}

Received March 8, 1989

\begin{abstract}
A thermostable purine nucleoside phosphorylase has been purified more than 800 -fold from Bacillus stearothermophilus JTS 859. The enzyme had a molecular weight of 68,000 consisting of 2 identical subunits $\left(M_{w}, 34,000\right)$. The isoelectric point of the enzyme was 4.7. The enzyme did not contain cysteine. The optimal pH of the enzyme reaction was from 7.5 to 11.0. The Michaelis constants for inosine, guanosine, $2^{\prime}$-deoxyinosine, and $2^{\prime}$-deoxyguanosine were $0.22,0.14,0.20$, and $0.10 \mathrm{mM}$, respectively. The optimal temperature of the reaction was $80 \mathrm{C}$. The half-life of the enzyme was $16 \mathrm{hr}$ in $20 \mathrm{mM}$ potassium phosphate and $1 \mathrm{mM}$ inosine $(\mathrm{pH} \mathrm{7.0)}$ at $80 \mathrm{C}$, and no decrease of the enzyme activity was observed at least for the first $30 \mathrm{hr}$ at $70^{\circ} \mathrm{C}$.
\end{abstract}

Purine nucleoside phosphorylase (PUNP) (EC 2.4.2.1) catalyzes the reversible phosphorolysis of ribonucleoside and 2'-deoxyribonucleoside derivatives of hypoxanthine, guanine, and xanthine as follows:

\section{Purine nucleoside + phosphate $\rightleftarrows$ purine base + pentose-1-phosphate.}

As the substrate specificity of the enzyme is not strict, it has been used to prepare nucleoside analogues such as 6-(dimethylamino)-9-( $\beta$-D2 '-deoxyribosyl)purine, $\alpha$-L-lyxosylhypoxanthine, virazole, and so on. ${ }^{1 \sim 3)}$ PUNP derived from methophiles has been used for this purpose.

The use of thermostable enzymes has several advantages. ${ }^{4}$ Enzymatic reactions can be done at high temperatures, and reaction rates are also high. Further, higher yields of enzyme would result due to greater enzyme stability at ordinary temperatures. In this study, puriffcation was done at room temperature, except for dialysis. Thermostable enzyme reactors are tolerant of bacterial contamination due to the high operation temperature. This is important for practical application because the usual enzyme reactors tend to be contaminated by bacteria.

We reported in our previous paper that a thermophile, Bacillus stearothermophilus JTS 859 , produces a thermostable PUNP. ${ }^{5)}$ Its half-life in the crude enzyme solution was $7200 \mathrm{hr}$ and $150 \mathrm{hr}$ at $63^{\circ} \mathrm{C}$ and $70^{\circ} \mathrm{C}$, respectively. This paper describes the purification of the thermostable PUNP from $B$. stearothermophilus JTS 859 and its properties.

\section{Materials and Methods}

Microorganism. Bacillus stearothermophilus JTS 859 , which produced a thermostable purine nucleoside phosphorylase, was used as the enzyme source.

Chemicals. Inosine was purchased from Yamasa Chemicals (Tokyo). Peptone A and yeast extract were purchased from Kyokuto Co. (Tokyo).

Culture conditions. Medium, containing ( $\mathrm{g} / 1$ of water) Peptone A 20 , yeast extract 10 , glucose 3 , inosine 1 , and $\mathrm{NaCl} 3$ ( $\mathrm{pH}$ 6.0) was used for cultivation. Spores $\left(3.2 \times 10^{7}\right)$ on a slant were transferred to 21 of the medium in a jar fermentor. Cultivation was done at $680 \mathrm{rpm}$ of two flat-blade impellers having 4 upper and 6 under blades (impeller diameter $60 \mathrm{~mm}$ ) with $1.5 \mathrm{vvm}$ aeration at $65^{\circ} \mathrm{C}$ for $8 \mathrm{hr}$. The $\mathrm{pH}$ of the medium was maintained from 5.9 
to 6.2 by a $\mathrm{pH}$ stat during cultivation. The cells were harvested by centrifugation $\left(10,000 \times g, 4^{\circ} \mathrm{C}, 15 \mathrm{~min}\right)$.

Enzyme assay. The standard reaction mixture consisting of $20 \mathrm{~mm}$ inosine, $20 \mathrm{~mm}$ potassium phosphate, and $50 \mu \mathrm{l}$ of enzyme solution in a total volume of $1 \mathrm{ml}(\mathrm{pH} 7.0)$ was incubated at $60^{\circ} \mathrm{C}$ for $20 \mathrm{~min}$. Fifty $\mu \mathrm{l}$ of the reaction mixture was transferred to $950 \mu \mathrm{l}$ of $\mathrm{MeOH}$ to stop the reaction. The hypoxanthine formed was measured by HPLC.

Analysis. The bases and nucleosides were identified and measured by HPLC. The operating conditions were: column, Chemcosorb 5-ODS-H $(\phi 4 \times 300 \mathrm{~mm})$ (Chemco Scientific Co, Ltd); column temperature $38^{\circ} \mathrm{C}$; solvent, water-MeOH = 95: $5(\mathrm{v} / \mathrm{v})$; flow rate, $0.8 \mathrm{ml} / \mathrm{min}$; detector, UV monitor $254 \mathrm{~nm}$.

Protein assay. Protein was measured by the method of Lowry et al. using bovine serum albumin as a standard. ${ }^{6}$ )

Measurement of molecular weight. The operating conditions of gel filtration were: column, TSK gel G3000SW ( $\phi 7.5 \times 600 \mathrm{~mm}$ ) (Tosoh Co, Tokyo); solvent, $200 \mathrm{~mm}$ potassium phosphate $(\mathrm{pH} 6.8$ ); flow rate, $0.5 \mathrm{ml} / \mathrm{min}$; detector, UV monitor $280 \mathrm{~nm}$. Ribonuclease A $\left(M_{w}\right.$ $13.7 \mathrm{k})$, chymotrypsinogen $\left(M_{w}, 25 \mathrm{k}\right)$, ovalbumin $\left(M_{w}\right.$ $45 \mathrm{k})$, bovine serum albumin $\left(M_{w} 67 \mathrm{k}\right)$, catalase $\left(M_{w}\right.$ $240 \mathrm{k}$ ), and ferritin $\left(M_{w} 440 \mathrm{k}\right)$ were used as standards.

Sodium dodecyl sulfate-polyacrylamide gel electrophoresis was done by the method of Laemmli $^{7}$

Amino acid analysis. The enzyme $(20 \mu \mathrm{g})$ was hydrolyzed in $6 \mathrm{~N} \mathrm{HCl}$ containing $4 \%$ thioglycolic acid $(400 \mu \mathrm{l})$ at $110^{\circ} \mathrm{C}$ for $22 \mathrm{hr}$ and $70 \mathrm{hr}$. Amino acid analysis was done with a Hitachi 835 amino acid analyzer.

\section{Results}

\section{Purification}

All purification procedures were at room temperature except dialysis $\left(4^{\circ} \mathrm{C}\right)$. The $20 \mathrm{~mm}$ potassium phosphate buffer $(\mathrm{pH} 7.0)$ used for the purification is referred as "the buffer" in the text.

Step 1. Cell free extract. Cells $(160 \mathrm{~g})$ suspended in the buffer $(500 \mathrm{ml})$ were collapsed by a Dyno-mill KDL type (Willy A. Bachofen AG., Basel, Switzerland) for $3.6 \mathrm{~min}$. The buffer was added to the resulting suspension up to $1400 \mathrm{ml}$. After centrifugation $\left(8300 \times g, 4^{\circ} \mathrm{C}\right.$, $20 \mathrm{~min}$ ), $1300 \mathrm{ml}$ of supernatant was obtained. The precipitate was suspended in the buffer $(500 \mathrm{ml})$ and the suspension was treated by the
Dyno-mill ( $5 \mathrm{~min}$ ) again. The buffer was added to the resulting suspension up to $1030 \mathrm{ml}$. After centrifugation $\left(8300 \times g, 4^{\circ} \mathrm{C}, 20 \mathrm{~min}\right)$, the supernatant obtained was combined with the supernatant above.

Step 2. Heat treatment. The combined supernatant was kept at $63^{\circ} \mathrm{C}$ for $1 \mathrm{hr}$ with gentle agitation. After centrifugation $(8300 \times$ $\left.g, 4^{\circ} \mathrm{C}, 20 \mathrm{~min}\right) 2130 \mathrm{ml}$ of supernatant was obtained.

Step 3. Acetone treatment. After adding a solution $\left(-10^{\circ} \mathrm{C}\right)$ consisting of acetone $(200 \mathrm{ml})$ and the buffer $(200 \mathrm{ml})$ to the heattreated supernatant, 1.81 of acetone $\left(-10^{\circ} \mathrm{C}\right)$ was added to it. This was kept at $5 \sim 10^{\circ} \mathrm{C}$ for $15 \mathrm{~min}$ with gentle agitation. After removing the precipitate by centrifugation $(9000 \times g$, $\left.4^{\circ} \mathrm{C}, 5 \mathrm{~min}\right), 2.51$ of acetone $\left(-10^{\circ} \mathrm{C}\right)$ was added to the supernatant. It was kept at $5 \sim 10^{\circ} \mathrm{C}$ for $15 \mathrm{~min}$ with gentle agitation. After centrifugation $\left(9000 \times \mathrm{g}, 4^{\circ} \mathrm{C}, 5 \mathrm{~min}\right)$, the collected precipitate was dissolved in the buffer $(800 \mathrm{ml})$.

Step 4. Acid treatmen. The enzyme solution was adjusted to $\mathrm{pH} 4.5$ with $1 \mathrm{M}$ phosphoric acid and it was kept at $4^{\circ} \mathrm{C}$ for 1 hr with gentle agitation. After centrifugation $\left(8900 \times g, 4^{\circ} \mathrm{C}\right.$, $1 \mathrm{hr}$ ), the $\mathrm{pH}$ of the supernatant was adjusted to $\mathrm{pH} 7.0$ with $1 \mathrm{M} \mathrm{KOH}$.

Step 5. DEAE-Toyopearl 650M chromatography. The enzyme solution $(800 \mathrm{ml})$ was applied on a column of DEAE-Toyopearl $650 \mathrm{M}$ (200 $\mathrm{ml})$ (Tosoh Co., Tokyo). The enzyme was eluted with the buffer (21) and with 11 each of buffer supplemented with 50, 100, 150 , and $200 \mathrm{~mm} \mathrm{NaCl}$. The enzyme activity was found in two different fractions. The enzyme, eluted with the buffer supplemented with $50 \mathrm{~mm} \mathrm{NaCl}(500 \mathrm{ml})$, was named PUNPI and the purification and characterization of PUNPI is described in this report. The other enzyme, eluted with the buffer supplemented with $200 \mathrm{~mm} \mathrm{NaCl}(500 \mathrm{ml})$, was named PUNPII, which will be reported on elsewhere.

Step 6. Second DEAE-Toyopearl 650M chromatography. The enzym solution, adjusted to $\mathrm{pH} 8.0$ with $1 \mathrm{M} \mathrm{KOH}$, was applied on a column of DEAE-Toyopearl $650 \mathrm{M}(400 \mathrm{ml})$ (Tosoh Co.). The enzyme was eluted with 
a linear $\mathrm{NaCl}$ gradient from $50 \mathrm{~mm}$ to $200 \mathrm{~mm}$ in the buffer. The active fractions $(166 \mathrm{ml})$ were collected.

Step 7. CM-Toyopearl 650M chromatography. The enzyme solution, adjusted to $\mathrm{pH}$ 4.0 with $2 \mathrm{~m}$ lactic acid, was applied on a column of CM-Toyopearl $650 \mathrm{M}(200 \mathrm{ml})$ (Tosoh Co.). The enzyme was eluted with the buffer supplemented with $400 \mathrm{mM} \mathrm{NaCl}(\mathrm{pH}$ 4.0). The eluate was adjusted to $\mathrm{pH} 7.0$ with $2 \mathrm{M} \mathrm{KOH}$.

Step 8. Butyl Toyopearl $650 \mathrm{M}$ chromatography. The enzyme solution $(50 \mathrm{ml})$ to which $9.8 \mathrm{~g}$ ammonium sulfate was added, was applied on a column of Butyl Toyopearl $650 \mathrm{M}$ $(50 \mathrm{ml})$ (Tosoh Co.). The enzyme was eluted with a linear ammonium sulfate gradient from $1.5 \mathrm{M}$ to $0 \mathrm{M}$ in the buffer.

Step 9. TSK gel DEAE 5PW chromatography. After the enzyme solution dialyzed against the buffer, was concentrated by ultrafiltration to $5 \mathrm{ml}$, it was applied on a column of TSK gel DEAE 5PW $(\phi 7.5 \times 75 \mathrm{~mm})$ (Tosoh Co.). The enzyme was eluted with a linear $\mathrm{NaCl}$ gradient from $90 \mathrm{~mm}$ to $150 \mathrm{~mm}$ in the buffer.

Step 10. TSK gel Phenyl 5PW chromatography. The enzyme solution $(17.8 \mathrm{ml})$, to which ammonium sulfate was added to $1.5 \mathrm{M}$, was applied on a column of TSK gel 5PW ( $\phi$ $7.5 \times 75 \mathrm{~mm}$ ) (Tosoh Co.). The enzyme was eluted with a linear ammonium sulfate gradient from $1.5 \mathrm{M}$ to $0.75 \mathrm{M}$ in the buffer. The active fraction $(26 \mathrm{ml})$ was collected.

Step 11. TSK gel G3000SW chromatography. The enzyme solution was applied on a column of TSK gel G3000SW ( $\phi 7.5 \times 600 \mathrm{~mm})$ (Tosoh Co.). The enzyme was eluted with the buffer supplemented with $1.5 \mathrm{M}$ glycerol at the flow rate of $0.5 \mathrm{ml} / \mathrm{min}$.

Step 12. TSK gel HA-1000 chromatography.

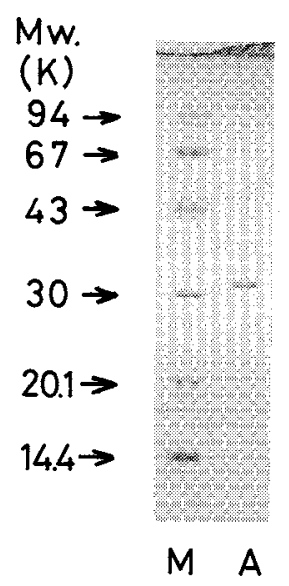

Fig. 1. SDS-Polyacrylamide Gel Electrophoresis.

Lane (A) PUNPI, $2 \mu \mathrm{g}$; Lane (M) phosphorylase B ( $M_{\mathrm{w}}$, $94 \mathrm{k}), 3 \mu \mathrm{g}$, bovine serum albumin $\left(M_{w}, 67 \mathrm{k}\right), 3 \mu \mathrm{g}$, ovalbumin $\left(M_{w}, 43 \mathrm{k}\right), 3 \mu \mathrm{g}$, carbonic anhydrase $\left(M_{w}, 67 \mathrm{k}\right)$, $3 \mu \mathrm{g}$, ovalbumin $\left(M_{w}, 43 \mathrm{k}\right), 3 \mu \mathrm{g}$, carbonic anhydrase $\left(M_{w}\right.$, $30 \mathrm{k}), 3 \mu \mathrm{g}$, soybean trypsin inhibitor $\left(M_{w}, 20.1 \mathrm{k}\right), 3 \mu \mathrm{g}$, and $\alpha$-lactoalbumin $\left(M_{w}, 14.4 \mathrm{k}\right), 3 \mu \mathrm{g}$.

Table I. Purification of Purine Nucleoside Phosphorylase

\begin{tabular}{llccc}
\hline Purification step & $\begin{array}{c}\text { Total protein } \\
(\mathrm{mg})\end{array}$ & $\begin{array}{c}\text { Total activity } \\
(\mu \mathrm{mol} / \mathrm{min})\end{array}$ & $\begin{array}{c}\text { Specific activity } \\
(\mu \mathrm{mol} / \mathrm{min} / \mathrm{mg})\end{array}$ \\
\hline 1. & Dyno mill & 22,800 & 11,200 & 0.49 \\
2. & Heat treatment & 18,200 & 11,100 & 0.61 \\
3. Acetone treatment & 12,800 & 8,400 & 0.66 \\
4. Acid treatment & 2,800 & 8,100 & 2.9 \\
5. & 1st DEAE-Toyopearl & 550 & 4,000 & 7.3 \\
6. & 2nd DEAE-Toyopearl & 232 & 3,320 & 14.3 \\
7. & CM-Toyopearl & 83.5 & 3,300 & 133 \\
8. & Butyl Toyopearl & 8.1 & 2,940 & 324 \\
9. & TSK gel DEAE 5PW & 5.9 & 2,630 & 327 \\
10. TSK gel Phenyl 5PW & 5.7 & 1,930 & 280 \\
11. & TSK gel G3000SW & 1.7 & 1,600 & 405 \\
12. TSK gel HA-1000 & & 690 & \\
\hline
\end{tabular}

The enzymatic activity was measured by the method described in the text. 
The enzyme solution $(4.1 \mathrm{ml})$ was applied on a column of TSK gel HA-1000 $(\phi 7.5 \times 75 \mathrm{~mm})$ (Tosoh Co.). The enzyme was eluted with a linear potassium phosphate gradient from $90 \mathrm{~mm}$ to $100 \mathrm{~mm}$ (pH 6.8). The collected enzyme solution was dialyzed against the buffer and it was used as the enzyme solution.

The enzyme PUNPI was homogeneous by sodium dodecyl sulfate-polyacrylamide gel electrophoresis (Fig. 1), by isoelectric focusing, and by gel filtration. The results of the purification are summarized in Table 1.

\section{Molecular weight}

The molecular weight of PUNPI was 68,000 by gel filtration and 34,000 by SDS-polyacrylamide gel electrophoresis (Fig. 1).

\section{Isoelectric point}

The isoelectric point of PUNPI was 4.7 by isoelectric focusing (PhastSystem, Pharmacia LKB Biotechnology).

\section{Amino acid composition}

The amino acid composition of PUNPI was analyzed. The number of each of the amino acids per subunit was calculated based on the

Table II. Amino Acid Composition of Purine Nucleoside Phosphorylase from B. stearothermophilus JTS859

\begin{tabular}{cc}
\hline Amino acid & Residues/Subunit \\
\hline Asx & 22 \\
Thr & 11 \\
Ser & 8 \\
Glx & 34 \\
Gly & 27 \\
Ala & 29 \\
Val & 23 \\
Cys & 0 \\
Met & 10 \\
Ile & 23 \\
Leu & 19 \\
Tyr & 9 \\
Phe & 6 \\
Lys & 11 \\
His & 5 \\
Arg & 16 \\
Pro & 15 \\
Try & 0 \\
\hline
\end{tabular}

molecular weight of the subunit $\left(M_{w}, 34,000\right)$ (Table II). No cysteine was found in PUNPI.

\section{Effects of temperature on the reaction}

The reaction was done at $40 \sim 90^{\circ} \mathrm{C}$ (Fig. 2). $\mathrm{Up}$ to $80^{\circ} \mathrm{C}$, hypoxanthine was synthesized with time but heat denaturation was observed at $90^{\circ} \mathrm{C}$. When the reaction mixture was heated at $90^{\circ} \mathrm{C}$ for $1 \mathrm{hr}$ without the enzyme, no hypoxanthine was released.

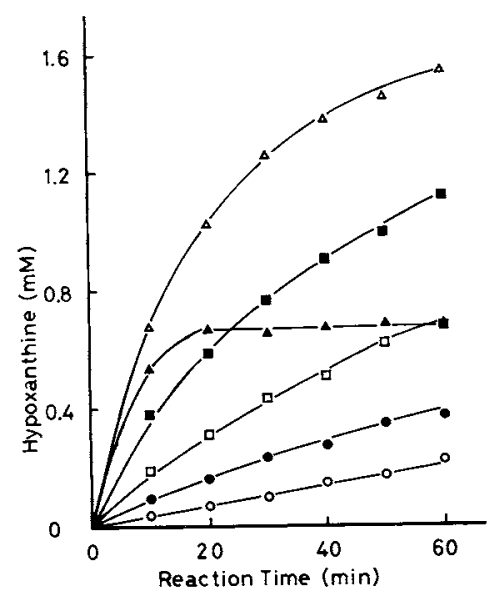

Fig. 2. Effects of Temperature.

The reaction mixture, containing $0.085 \mu \mathrm{g}$ PUNPI in $20 \mathrm{~mm}$ inosine and $20 \mathrm{~mm}$ potassium phosphate $(\mathrm{pH} 7.0)$ in a total volume of $1 \mathrm{ml}$ was incubated at various temperatures. $\bigcirc, 40^{\circ} \mathrm{C} ; \bigcirc, 50^{\circ} \mathrm{C} ; \square, 60^{\circ} \mathrm{C} ; \square, 70^{\circ} \mathrm{C} ; \triangle, 80^{\circ} \mathrm{C} ;$ $90^{\circ} \mathrm{C}$.

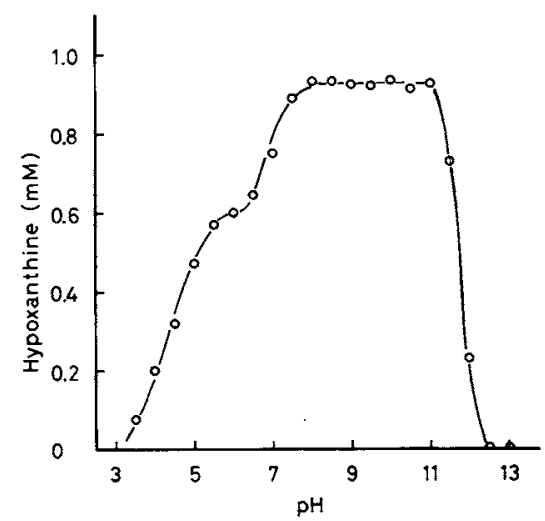

Fig. 3. Effects of $\mathrm{pH}$.

The reaction mixture, containing $0.68 \mu \mathrm{g}$ PUNPI in $20 \mathrm{~mm}$ inosine and $20 \mathrm{~mm}$ potassium phosphate at various $\mathrm{pHs}$ in a total volume of $5 \mathrm{ml}$, was incubated at $60^{\circ} \mathrm{C}$ for $15 \mathrm{~min}$. 
Table III. $K m$ Values

The reaction mixture, containing $0.085 \mu \mathrm{g}$ PUNPI in $100 \mathrm{~mm}$ potassium phosphate and various concentrations of substrate $(\mathrm{pH} 7.0)$ in a total volume of $5 \mathrm{ml}$, was incubated at $60^{\circ} \mathrm{C}$.

\begin{tabular}{lcc}
\hline Substrate & $K m(\mathrm{mM})$ & Relative $V_{\max }$ \\
\hline Inosine & 0.22 & 100 \\
Guanosine & 0.14 & 133 \\
2'-Deoxyinosine & 0.20 & 100 \\
2'-Deoxyguanosine & 0.10 & 135 \\
\hline
\end{tabular}

Table IV. EFFECTS OF INHIBITORS

The reaction mixture containing $0.09 \mu \mathrm{g}$ PUNPI in $1 \mathrm{~mm}$ inhibitor, $20 \mathrm{~mm}$ inosine, and $20 \mathrm{~mm}$ potassium phosphate ( $\mathrm{pH} \mathrm{7.0)}$ in a volume of $1 \mathrm{ml}$ was incubated at $60^{\circ} \mathrm{C}$ for $20 \mathrm{~min}$. Liberated hypoxanthine was measured.

\begin{tabular}{ll}
\hline Inhibitor & $\begin{array}{c}\text { Hypoxanthine } \\
(\mathrm{mM}) \pm \text { S.D. }\end{array}$ \\
\hline Control & $0.51 \pm 0.03$ \\
$\mathrm{PCMB}^{a}$ & 0 \\
$\mathrm{HgCl}_{2}$ & 0 \\
lodoacetic acid & $0.51 \pm 0.03$
\end{tabular}

a PCMB, p-chlormercuribenzoic acid.

$b$ S.D., standard deviation $(n=3)$.

\section{Effects of $p H$ on the reaction}

A very broad pH-activity profile was obtained as shown in Fig. 3. The optimal $\mathrm{pH}$ was from 7.5 to 11.0 . When the reaction was done in McIlvaine buffer containing $20 \mathrm{~mm}$ potassium phosphate ( $\mathrm{pH} 3.5 \sim 7.0$ ) and in $20 \mathrm{~mm}$ Tris $\cdot \mathrm{HCl}$ buffer containing $20 \mathrm{~mm}$ potassium phosphate $(\mathrm{pH} 7.0 \sim 9.5)$, the pH-activity profile in these buffers were similar to that in potassium phosphate buffer (data not shown).

\section{$K m$}

$\mathrm{Km}$ values were measured as shown in Table III. PUNPI could not catalyze the phosphorolysis of adenosine, 2'-deoxyadenosine, or pyrimidine nucleosides.

\section{Effects of inhibitors on the reaction}

The effects of sulfhydryl reagents on PUNPI were examined as shown in Table IV. PUNPI was completely inactivated by $\mathrm{PCMB}$ and

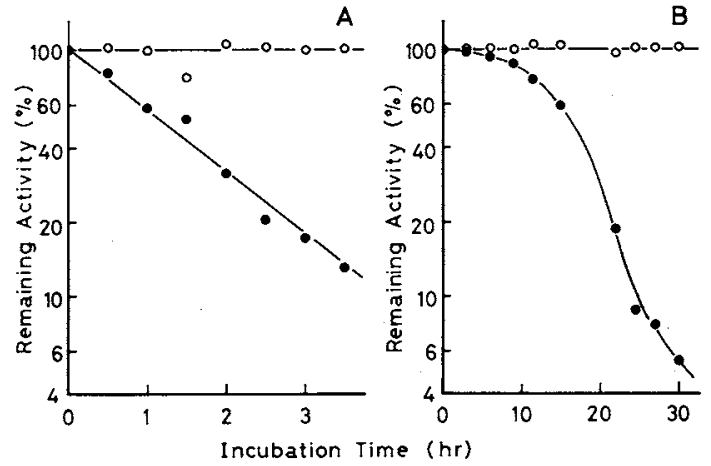

Fig. 4. Thermostability of PUNPI

PUNPI $(1.7 \mu \mathrm{g} / \mathrm{ml})$ was kept in $20 \mathrm{~mm}$ potassium phosphate $(\mathrm{pH} \mathrm{7.0)}$ (A) and in $20 \mathrm{~mm}$ potassium phosphate and $1 \mathrm{~mm}$ inosine $(\mathrm{pH} 7.0)(\mathrm{B})$ at 70 and $80^{\circ} \mathrm{C}$. The remaining activity was measured by the method described in the text. $\bigcirc, 70^{\circ} \mathrm{C} ; 80^{\circ} \mathrm{C}$.

$\mathrm{HgCl}_{2}$ but was not inactivated by iodoacetic acid at a concentration of $1 \mathrm{~mm}$.

\section{Thermostability of PUNPI}

As PUNPI was denatured at $90^{\circ} \mathrm{C}$ as shown in Fig. 2, the thermostability of PUNPI was examined at $70^{\circ} \mathrm{C}$ and $80^{\circ} \mathrm{C}$, and the effects of the substrate, inosine on the thermostability were also examined (Fig. 4). Half-life of PUNPI was $74 \mathrm{~min}$ in $20 \mathrm{~mm}$ potassium phosphate and $16 \mathrm{hr}$ in $20 \mathrm{~mm}$ potassium phosphate and $1 \mathrm{~mm}$ inosine at $80^{\circ} \mathrm{C}$. Inactivation of PUNPI was not observed at $70^{\circ} \mathrm{C}$ for the first $30 \mathrm{hr}$.

\section{Discussion}

Thermostable PUNP was purified more than 826-fold from a thermophile, B. stearothermophilus JTS859. The PUNPI had an apparent molecular weight of 68,000 with a subunit molecular weight of 34,000 , suggesting that the PUNPI consisted of 2 identical subunits. The $K m$ for inosine was $0.22 \mathrm{~mm}$. It was almost the same as that of $B$. subtilis enzymes. ${ }^{8)}$

The reported PUNPs have been identified as SH-enzymes. ${ }^{9 \sim 11)}$ The effects of $\mathrm{pH}$ on the reaction, the effects of sulfhydryl reagents of the reaction, and the amino acid composition 
of PUNPI were identified to clarify whether PUNPI was a SH-enzyme or nor. The optimal $\mathrm{pH}$ range of PUNPI was very broad, $\mathrm{pH}$ $7.5 \sim 11.0$ (Fig. 3). On the other hand the optimal $\mathrm{pH}$ range of the reported PUNPs is within $2 \mathrm{pH}$ units including $\mathrm{pH} 7.0 .^{9 \sim 12)}$ The effects of $\mathrm{pH}$ on the kinetic properties of the PUNP obtained from rabbit liver and human erythrocytes were investigated in detail. ${ }^{9.10)}$ In both cases, the plots of $\log V_{\max }$ versus $\mathrm{pH}$ showed that the enzymatic activity changed at about $\mathrm{pH} 8.1$ and $\mathrm{pH} 8.5$, respectively, suggesting the presence of sulfhydryl groups of cysteine $\left(\mathrm{p} K_{\mathrm{a}} 8.3\right)$ at the active site of the enzyme. However, the enzymatic activity of PUNPI was almost the same over $\mathrm{pHs}$ from 7.5 to 11.0 (Fig. 3). Further, the amino acid analysis showed that PUNPI did not contain cysteine (Table II). These facts suggest that sulfhydryl groups may not been involved in the active site of PUNPI. On the other hand, PUNPI was inhibited by sulfhydryl reagents, as shown in Table IV. As these results were contradictory, further studies are necessary.

The optimal temperature of the raction was $80^{\circ} \mathrm{C}$ (Fig. 2). The half-life of the enzyme was $16 \mathrm{hr}$ in $20 \mathrm{~mm}$ potassium phosphate and $1 \mathrm{~mm}$ inosine $(\mathrm{pH} 7.0)$ at $80^{\circ} \mathrm{C}$ and was $74 \mathrm{~min}$ in $20 \mathrm{~mm}$ potassium phosphate $(\mathrm{pH} 7.0)$ at $80^{\circ} \mathrm{C}$ (Fig. 4). Stabilization of the enzyme by the presence of the substrate, inosine, was also observed in this case. ${ }^{13)}$ The decrease of enzyme activity was not observed at $70^{\circ} \mathrm{C}$. The thermostabilities of PUNP obtained from mesophiles at high temperatures have been reported. The residual activity of the PUNP obtained from Enterobacter cloacae was $12.5 \%$ after $30 \mathrm{~min}$ of heating at $70^{\circ} \mathrm{C}$ in $100 \mathrm{~mm}$
Tris $\cdot \mathrm{HCl}$ buffer $\left.(\mathrm{pH} 7.0) .{ }^{14}\right)$ The half-life of the PUNP obtained from Salmonella typhimurium was $59 \mathrm{~min}$ in $200 \mathrm{~mm}$ potassium phosphate and $2 \mathrm{~mm} 2^{\prime}$-deoxyinosine at $69^{\circ} \mathrm{C}(\mathrm{pH} 7.1) .{ }^{13)}$ Compared to the thermostability of these PUNPs obtained from mesophiles, PUNPI was extremely stable at high temperature, $80^{\circ} \mathrm{C}$. Due to this thermostability, PUNPI is useful for practical applications.

\section{References}

1) T. A. Krenitsky, G. W. Koszalka and J. V. Tuttle, Biochemistry, 20, 121 (1986).

2) J. D. Stoeckler, C. Cambor and R. E. Parks, Jr., Biochemistry, 19, 102 (1980).

3) T. Utagawa, H. Morisawa, S. Yamanaka, A Yamazaki and Y. Hirose, Agric. Biol. Chem., 50, 121 (1986)

4) A. Fichter ed. Advances in Biochemical Engineering/Biotechnology, 28, 69 (1983)

5) N. Hori, M. Watanabe, Y. Yamazaki and Y. Mikami, Agric. Biol. Chem., 53, 197 (1989).

6) O. H. Lowry, N. J. Rosebrough, A. L. Farr and R. J. Randall, J. Biol. Chem., 193, 265 (1951).

7) U. K. Laemmli, Nature, 227, 680 (1970)

8) K. F. Jensen, Biochim. Biophysica. Acta, 525, 346 (1978)

9) A. S. Lewis and M. D. Glantz, J. Biol. Chem., 251, 407 (1976).

10) R. P. Agarwal and R. E. Parks, Jr., J. Biol. Chem., 244, 644 (1969).

11) A. S. Lewis and M. D. Glantz, Biochemistry, 15, 4451 (1976).

12) T. Utagawa, H. Morisawa, S. Yamanaka, A. Yamazaki, F. Yosinaga and Y. Hirose, Agric. Biol. Chem., 49, 3239 (1985).

13) K. F. Jensen and P. Nygaard, Eur. J. Biochem., 51, 253 (1975).

14) Y. Machida and T. Nakanishi, Agric. Biol. Chem., 45, 1801 (1981). 